\title{
Cardiac biomarkers alterations in patients with SARS-CoV-2 infection
}

\author{
ELEOUSA OIKONOMOU, THEMISTOKLIS PARASKEVAS, DIMITRIOS VELISSARIS
}

Department of Internal Medicine, University Hospital of Patras, Greece

\begin{abstract}
Reliable biomarkers are necessary for the risk stratification of patients infected with SARS-CoV-2. This novel coronavirus is now established to affect several organs in addition to the lungs, most prominently the heart. This is achieved through direct damage to the myocardium and indirect immune-associated effects during the cytokine storm. We performed a literature review aiming to identify the prognostic value of alterations of cardiac biomarkers in SARS-CoV-2 infection. Cardiac biomarkers are significantly elevated in patients with severe COVID-19 and are independent predictors of mortality. High-sensitivity troponin I and T are correlated with multiple inflammatory indexes and poor outcomes. Although cut-off values have been established for most of cardiac biomarkers, lower limits for troponins may have better prognostic values and longitudinal monitoring of cardiac biomarkers can help the clinician assess the patient's course. Additional measurements of NT-proBNP, can detect the subgroup of patients with poor prognosis.
\end{abstract}

Key words: SARS-CoV-2, biomarkers, troponins, natriuritic peptides, prognosis.

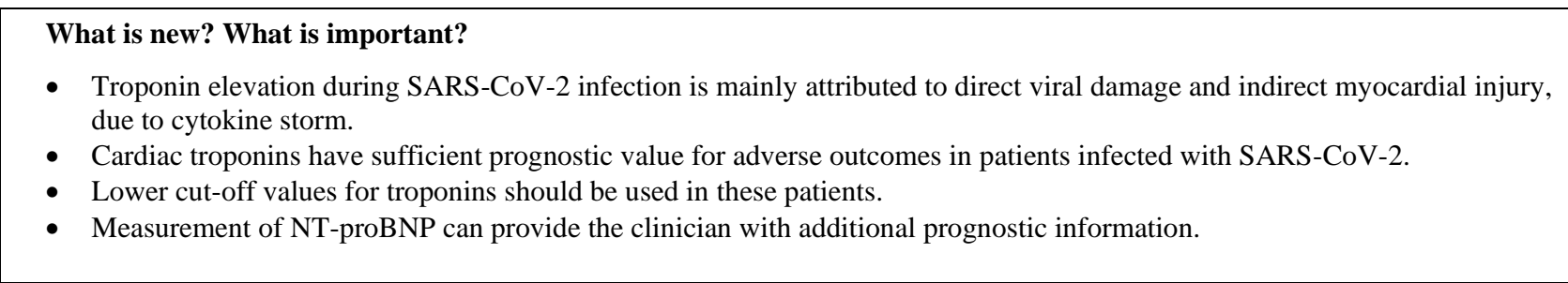

\section{INTRODUCTION}

The coronavirus disease 2019 (COVID-19) is a worldwide public health emergency evoked by SARS-CoV-2 which primarily targets the respiratory system. However, cardiovascular involvement is present and occasionally profound, including disorders such as myocardial injury, myocarditis, pericarditis, cardiomyopathy, heart failure, cardiogenic shock, arrhythmia and cardiac arrest. Abnormal plasma levels of cardiac biomarkers were described by early reports from patients in Wuhan, and since then, a plethora of studies have focused on their clinical significance. In this report, we summarize the findings of current literature concerning cardiac biomarkers in COVID-19 with emphasis on cardiac troponins.

\section{Pathophysiology}

Several putative mechanisms of the underlying cardiac injury during the process of
SARS-CoV-2 infection have been reported in accumulating studies, which conclude that myocardial damage - defined by increased troponins - can be caused either by direct viral infection, or secondary to systemic events [1].

\section{Direct myocardial damage}

Angiotensin-Converting Enzyme receptor 2 (ACE2) is a monocarboxylate and component of the Renin-Angiotensin-Aldosterone System (RAAS). Briefly, the role of ACE2 is to metabolize angiotensin II to angiotensin (1-7) and secondary convert Ang I to Ang-(1-9), which is further converted by ACE into Ang-(1-7). The effect of this sequence is the reduction of blood pressure in the systemic circulation [2]. ACE2 is identified as a cellular receptor of SARS-CoV-2, predominantly expressed by epithelial cells of several human organs including the lungs, heart, kidney, blood vessels, brain, and small intestine. [3-6]. On this basis, viral penetration into these 
organs, clinically apparent or not, is a possible scenario during SARS-CoV-2 infection [4]. In regards to the cardiac tissue, the high expression of ACE2 in the myocardium, provides an entry point for the coronavirus to insert into the target host cells and replicate rapidly, resulting in acute myocarditis. In this setting, ACE2 is downregulated through binding of the viral surface spike glycoprotein to ACE2, while ACE functions normally, converting Ang I to Ang II. As ACE2 normally antagonizes ACE, the decreased ACE2 level, upon viral infection, de-regulates the balance of RAAS, inhibiting the cardio-protective role of Ang-(1-7) [7]. Underlying consequences are accumulation of Ang II and pro-inflammatory cytokines, vasoconstriction, pro-oxidative effects, and subsequent cardiovascular injury [6,8]. Thus, a potential mechanism of acute myocardial cells' damage and viral myocarditis, during SARS-CoV-2 infection, could occur by way of ACE-2 signaling.

\section{Indirect myocardial injury}

In addition to the direct virus-induced myocardial damage, de-regulation of cardiac function can be caused by hyper-inflammation and underlying increased cytokine secretion. This key pathogenetic mechanism, named "cytokine storm", is characterized by high immune cell proliferation, resulting in profound and uncontrolled immune response, with continued activation of monocytes, macrophages, granulocytes, and natural killer cells [8]. These inflammatory mediators contribute to the overproduction of abundant pro-inflammatory cytokines including interleukin (IL)-1 $\beta$, IL-6, granulocyte colony stimulating factor (GCSF) and tumor necrosis factor- $\alpha$ (TNF- $\alpha)$, IFN- $\gamma$, monocyte chemo-attractant protein 1 (MCP-1) and macrophage inflammatory protein $1 \mathrm{~A}$ (MIP1A) [5,8,9]. Consequences of these are the creation of a positive feedback cycle which maintains the robust and dysfunctional immune response, causing damage to the myocardium and impeding mechanical cardiac function, among patients with COVID-19 [3,8,10].

Another plausible mechanism of indirect myocardial injury is the Acute Respiratory Distress Syndrome (ARDS)-induced hypoxia, which leads to poor oxygen supply to the cardiac muscle, and an increase of the right ventricular pressure and volume overload, creating supplydemand mismatch and ischemic cardiac damage. Endothelial injury, micro-thrombi caused by hypercoagulability and arrhythmias further burden the cardiac and pulmonary function [1].

\section{Cardiac troponins}

Cardiac troponin $\mathrm{T}$ and $\mathrm{I}$ are cytoplasmic proteins found in the cardiac myocytes and regulate muscle contraction by binding to the actintropomyosin complex. As a response to myocardial damage, these proteins are released in the bloodstream, but hypertroponinemia can be present in a variety of non-cardiac diseases. In clinical practice, they are used to identify potential myocardial injury and most importantly myocardial infraction and can provide prognostic information in cardiomyopathies and stroke. Apart from acute coronary syndromes, increased troponin levels can be found in patients with tachyarrhythmias, heart failure, pulmonary hypertension, ARDS and systemic diseases such as sepsis. The lack of standardization in the immunoassays used to determine cardiac troponin values, can lead to difficulties in the comparison of results from different studies, when only absolute troponin values are reported. Thus, current literature suggests the use the 99th percentile of upper range limit instead.

During the first period of the pandemic, increased troponin values described in patients in Wuhan were attributed to virus-related cardiac injury and were associated with poor prognosis [11]. Since then, elevated troponins have been associated with multiple adverse outcomes by a plethora of studies. Increased mortality has been reported for both patients with increased $\mathrm{TnI}$ and TnT [12,13]. Patients with severe disease or admitted in the ICU more often have elevated troponins and their values are significantly higher than those of patients with mild disease [14]. Abnormal hs-TnI levels were more common in older, male patients with higher rates of comorbidities [12,15-18]. According to a metaanalysis, patients with elevated TnI had increased risk of poor outcomes and were more likely to be admitted to the ICU [12]. In an observational retrospective study, $\mathrm{Mu}$ et al. [19] found positive correlations between cTnI and SOFA and APACHE score, but not CURB-65 score. It is noteworthy that higher mortality rates are associated with further increase in troponin values [20].

Multiple inflammatory indexes, including CRP, d-dimers and ferritin have been positively correlated with troponin elevation $[19,21,22]$, thus 
it is speculated that myocardial damage is of inflammatory origin. The results of a multicenter observational study, indicated a positive correlation of cTnI, d-dimers and $\mathrm{PO} 2 / \mathrm{FiO} 2(\mathrm{P} / \mathrm{F})$ ratio, raising the question, whether TnI elevation indicates a subset of patients with higher inflammatory responses [23], while they consider elevated proBNP indicative of prior cardiovascular disease as the main aggravating factor. On this matter, other researchers describe troponins and BNP as biomarkers of myocardial injury and cardiac stress, respectively [24].

\section{Prognostic value}

Original studies analyzing the prognostic value of cardiac troponins have shown promising results. Since myocardial damage in SARS-CoV-2 infection is mostly attributed to systemic inflammation rather than myocardial infarction, the standard cut-off values have been challenged, as they significantly underestimated cardiac injury in these patients [25]. Mild troponin elevation is common in SARS-CoV-2 infection and thus lower cut-off values have been proposed. For hs-TnI, the lowest cut-off values proposed are $6 \mathrm{ng} / \mathrm{L}$ and 7.8 $\mathrm{ng} / \mathrm{L}$ with sensitivity $95 \%$, specificity $52 \%$ and sensitivity $78 \%$, specificity $86 \%$ respectively, for prediction of death $[21,26]$. A cut-off value of 20 $\mathrm{ng} / \mathrm{L}$ may have greater prognostic value than $40 \mathrm{ng} / \mathrm{L}$, with a sensitivity and specificity of $85 \%$ for predicting 30-day mortality [27]. A similar value is proposed by Peiro et al., yields lower results (Sensitivity $81 \%$, Specificity $70 \%$ ), when measured on admission [16]. Lastly, a cut-off value of $40 \mathrm{ng} / \mathrm{L}$ provides great specificity $(94 \%)$ but low sensitivity (47\%) [26].

According to these data, it may be useful to use multiple cut-off points for making clinical decisions. Salvatici et al. suggest that due to its high specificity a cut-off point of $40 \mathrm{ng} / \mathrm{L}$, could help identify high-risk patients in need of aggressive therapeutic plans [26]. Clinicians should keep in mind that patients with supposedly normal values, still have increased risk for mortality and that absolute risk of death rises significantly when troponin is elevated more than two-folds [28]. It should be noted that, a retrospective study with over 1000 patients, found that patients with non-detectable hs-TnI levels on admission had $15 \%$ risk for ICU admission or death [29].

In comparison to inflammatory markers, hs-TnI has better predictive value $[16,26]$. Its ability to predict poor outcomes may be increased when combined with old age or elevated AST [30]. Moreover, the risk of death is increased when NT-proBNP is also elevated [23,24,31].

Although most studies agree that troponins can be used as prognostic biomarkers in SARSCoV-2 infection, the literature results are not equivocal. A study from Yao et al. argues that when adjusting for all comorbidities, hs-TnI loses its predictive value, and considers NT-proBNP superior instead [32]. Additionally, a retrospective observational study, report that hs-cTnT cannot be used to predict ICU admission [33].

The discrepancy between the findings of the studies could potentially be due to the use of different immunoassays. As experts suggest, percentile values of upper range limits should be used in studies instead of absolute values. More prospective multicenter studies on the prognostic value of troponins could help identify algorithms that will lead to evidence-based clinical decisions.

\section{Troponin trends}

Cardiac troponins are dynamic markers of myocardial injury and their values on different time points is indicative of the ongoing myocardial injury. Evidence shows that if hs-TnT values peak during the first day of admission, mortality and ICU stay decrease [34]. This applies to both patients with low and high hs-TnT levels on admission. Additionally, Li et al. reported that in survivors with severe disease hs-cTnI levels increased from admission to day three but then declined, while in non-survivors they abruptly increased before the patient's death [35]. Another study showed relatively unchanged values and a similar abrupt increase near death in nonsurvivors, and a steady downwards trend in survivors [26]. In addition, peak values of both hs-TnT and hs-TnI are associated with adverse outcomes, with peak cTnI values predicting the need for invasive ventilation [36,37]. Lastly, an elevated troponin level (above 99th percentile of Upper Range Limit), was found in $6.2 \%$ of survivors 1-4 weeks after hospital discharge, but without clinical or cardiovascular MRI evidence of heart dysfunction [38].

This evidence supports that besides measurement of troponins on admission, longitudinal monitoring, can help clinicians to assess better the patient's course. Also, close monitoring of troponin values during the first day of admission, provides prognostic information. 


\section{Comorbidities}

Cardiovascular comorbidities are common in severe COVID-19 disease, as these patients are often of old age. While the effect of cardiovascular disease on the course of SARSCoV-2 infection is outside of the scope of this report, it should be noted that in contrary to elevated hs-TnI levels, cardiovascular comorbidities were not an independent risk factor for inhospital mortality at multivariable analysis in an Italian study [39]. However, another retrospective study from Li et al. reported different results [40].

Tornero et al. published a study focusing on chronic heart failure (CHF) and SARS-CoV-2 with interesting results [41]. They reported a significant increase in mortality in patients with CHF $(n=43)$ and in this population, the mortality was associated with hs-TnT, but not NTproBNP. Additionally, they suggest that hs-TnT values above $14 \mathrm{ng} / \mathrm{L}$, indicate high risk patients. Elevated hs-TnT was found in most CHF patients, but surprisingly none of those with normal troponin levels died. Lastly, in this subset, a cutoff of $38 \mathrm{ng} / \mathrm{L}$ can be used to predict 30-day mortality (sensitivity $79 \%$, specificity $67 \%)$.

While hypertension is the most frequent comorbidity in SARS-CoV-2 patients [40], people with hypertension are not overrepresented amongst those with sever SARSCoV-2 infection, according to the International Society of Hypertension. Regarding cardiac biomarkers, in mild and moderate cases but not in severe infections, elevated hs-TnI (>26 ng/L) is more common in patients with hypertension than in those without [32]. In this subset of patients, dynamic changes of troponin levels were associated with increased risk of death. Smoother trends of median hs-TnI were also reported in patients without hypertension than those with.

Systemic inflammation and sympathetic activation during SARS-CoV-2 infection may induce cardiac arrhythmias, and their presence may promote a more pronounced troponin elevation $[36,42]$. Indeed, there is evidence that patients with elevated TnI have increased prevalence of ventricular and atrial tachyarrhythmias $[14,43]$ and that hs-TnT levels are significantly higher in patients with arrhythmia, than in those without [42]. The presence of elevated troponin levels and atrial tachyarrhythmias identifies a group of patients in high risk of death [36].

\section{Paraclinical findings}

The literature regarding echocardiographic findings and alterations in cardiac biomarkers is inconclusive and prone to selection bias. A retrospective study reported that although right ventricular $(\mathrm{RV})$ dysfunction is common in patients with elevated hs-TnI, there was no significant correlation between the two [44]. In contrary, the left ventricle was only seldomly impaired. In another multicenter study, TAPSE (Tricuspid Annular Plane Systolic Excursion) - an index for RV dysfunction - was significantly reduced in patients with abnormal hs-TnI and NT-proBNP [23]. Additional studies report results in favor of statistically significant correlation between cardiac biomarkers and ventricular dysfunction [13,45], as well as against it [23,46,47]. Prospective multicenter studies must be performed before any conclusions on this matter can be made.

The data on ECG and elevated troponins, in the current literature, are clearer. hs-TnT is significantly higher in patients with ECG abnormalities [36]. Additionally, elevated hs-TnI levels are associated with the presence of longer QTc interval, conduction disturbances and other ECG abnormalities, but not atrial fibrillation [48]. Wide QRS complex and abnormal lateral ST-T segment are more common in patients with elevated cardiac biomarkers [49]. Giustino et al. suggest that Transthoracic Echocardiography (TTE) may be considered in COVID-19 positive patients with elevated troponins and ST-segment changes, to identify patients with acute coronary syndromes that would benefit from invasive treatment [15]. In patients with troponin elevation attributed to Acute Coronary Syndromes (ACS), inflammatory biomarkers were lower, ECG changes were more pronounced, and all had regional-wall abnormalities in TTE. The latter was present only in $20 \%$ of patients with troponin elevation unrelated to ACS [15]. To our knowledge, the role of cardiac MRI in SARS-CoV-2 patients with troponin elevation, has not been systemically studied, but it could provide an alternative to TTE for non-invasive assessment of cardiac injury [50]. Myocarditis-like features were reported in the cardiac MRI of patients with unexplained troponin elevation [51].

\section{Natriuretic peptides}

NT-proBNP and BNP are cardiac biomarkers commonly used to diagnose heart failure and cardiac dysfunction. Increased 
intracardial pressure and mechanical stress induce the synthesis and secretion of natriuretic peptides. In the past, abnormal BNP and NT-proBNP values have been associated with worse clinical outcomes among patients with ARDS [52].

The literature on NT-proBNP in SARSCoV-2 infection is more scarce compared to troponin literature. A strong positive correlation between the two cardiac biomarkers has been described [22]. NT-proBNP is also correlated with inflammatory biomarkers and T-cell markers [53]. In parallel with troponins, NT-proBNP is more commonly elevated in non-survivors and metaanalyses have reported a significant association between NT-proBNP and mortality $[54,55]$. NTproBNP is an independent risk factor for negative outcomes and in clinical practice it could be used in conjunction with troponins, to detect patients with poor prognosis [31]. The proposed cut-off values for NT-proBNP in current literature are $88.64 \mathrm{pg} / \mathrm{mL}$ with a sensitivity $100 \%$ and specificity $67 \%$ for predicting in-hospital death and in the CHF subgroup $2598 \mathrm{pg} / \mathrm{ml}$ (sensitivity $91.7 \%$, specificity $80 \%$ ) [41,56]. In order to achieve more reliable prognosis in SARS-CoV-2 infection, further research should establish different cut-off values according to the patients' age, as is the norm for NT-proBNP. Contrariwise, studies reported that BNP is not a valid prognostic factor in COVID-19 patients [57,58].

\section{Miscellaneous biomarkers}

CK-MB and myoglobin are closely related to myocardial damage and as expected they are significantly elevated in severe SARS-CoV2 infection [54]. Their prognostic value in these patients is similar, but according to some studies, inferior to troponins'. As current literature is more focused on troponins than CK-MB and myoglobin, the use of troponins in clinical practice seems more appropriate.

GDF-15 belongs to the TGF-b superfamily and is a novel biomarker associated with inflammation, cardiac damage, and cancer. Its prognostic value in COVID-19 was reported to be greater than that of troponin and NT-proBNP, but more studies are needed to prove its potency [59].

\section{CONCLUSION}

The unprecedented and significant burden of the COVID-19 pandemic on the health system, has created an urgent need for practical and reliable prognostic tools, in order to facilitate stratification and management of patients. Our study highlights the role of cardiac biomarkers, and especially cardiac troponins, in modern emergency medicine in the context of SARS-CoV-2 infection. As their predictive value is now supported by many studies, future research should focus on how troponins can assist in evidence-based clinical decision making. Concerning hs-TnI, it is necessary to establish the use of percentile values, so that the results of different troponin studies can be compared reliably. Therefore, measurement of cardiac biomarkers on admission, combined with monitoring of their values during hospitalization, can provide the clinician with important information about the clinical course of COVID-19 patients.

Este nevoie de biomarkeri pentru stratificarea riscului la pacienții infectați cu SARS-CoV-2. Pe lângă plămâni, și inima este afectată de acest virus, fie direct, fie prin furtuna citokinică. A fost realizat un studiu extensiv al literaturii privind biomarkerii prognostici pentru afectarea miocardică în cadrul infecției cu virusul SARS-CoV-2. Biomarkerii cardiaci sunt modificați la pacienții cu infecție severă și sunt predictori independenți pentru mortalitate. Troponina I și T high sensitivity se corelează cu un efect prognostic prost. Analizând în plus nivelurile NT-proBNP se poate detecta subgrupul de pacienți cu prognostic prost.

Correspondence to: Dimitrios Velissaris MD, PhD

Associate Professor at University of Patras, Greece

E-mail: dvelissaris@ upatras.gr, mobile: 0030 6974909988, tel work: 00302610999583

Conflict of interest disclosure: The authors have no conflicts of interest to declare.

Funding sources: This research did not receive any financial support or sponsorship.

Author contributions: EO and TP did literature search and wrote the manuscript. EO and TP contributed equally in the manuscript. DV wrote the manuscript and supervised the study. 


\section{REFERENCES}

1. KURZ DJ, EBERLI FR. Cardiovascular aspects of COVID-19. Swiss Med Wkly. 2020;150:w20417.

2. BHALLA V, BLISH CA, SOUTH AM. A historical perspective on ACE2 in the COVID-19 era [published online ahead of print, 2020 Dec 14]. J Hum Hypertens. 2020;1-5.

3. BADER F, MANLA Y, ATALLAH B, STARLING RC. Heart failure and COVID-19. Heart Fail Rev. 2021;26(1):1-10.

4. IMAZIO M, KLINGEL K, KINDERMANN I, BRUCATO A, DE ROSA FG, ADLER Y, et al. COVID-19 pandemic and troponin: indirect myocardial injury, myocardial inflammation or myocarditis?. Heart. 2020;106(15):1127-1131.

5. LI L, ZHOU Q, XU J. Changes of Laboratory Cardiac Markers and Mechanisms of Cardiac Injury in Coronavirus Disease 2019. Biomed Res Int. 2020;2020:7413673.

6. ABOUGHDIR M, KIRWIN T, ABDUL KHADER A, WANG B. Prognostic Value of Cardiovascular Biomarkers in COVID-19: A Review. Viruses. 2020;12(5):527.

7. SHI X, CHEN M, ZHANG Y. The cardiovascular disorders and prognostic cardiac biomarkers in COVID-19. Mol Biol Rep. 2021;48(2):1763-1771.

8. WU L, O'KANE AM, PENG H, BI Y, MOTRIUK-SMITH D, REN J. SARS-CoV-2 and cardiovascular complications: From molecular mechanisms to pharmaceutical management. Biochem Pharmacol. 2020;178:114114.

9. ADEGHATE EA, EID N, SINGH J. Mechanisms of COVID-19-induced heart failure: a short review. Heart Fail Rev. 2021;26(2):363-369.

10. COSTA IBSDS, BITTAR CS, RIZK SI, ARAÚJO FILHO AE, SANTOS KAQ, MACHADO TIV, et al. The Heart and COVID-19: What Cardiologists Need to Know. O Coração e a COVID-19: O que o Cardiologista Precisa Saber. Arq Bras Cardiol. 2020;114(5):805-816.

11. HUANG C, WANG Y, LI X, REN L, ZHAO J, HU Y, et al. Clinical features of patients infected with 2019 novel coronavirus in Wuhan, China. Lancet. 2020;395(10223):497-506.

12. MALIK P, PATEL U, PATEL NH, SOMI S, SINGH J. Elevated cardiac troponin I as a predictor of outcomes in COVID-19 hospitalizations: a meta-analysis. Infez Med. 2020;28(4):500-506.

13. BAGATE F, MASI P, D'HUMIÈRES T, AL-ASSAAD L, CHAKRA LA, RAZAZI K, et al. Advanced echocardiographic phenotyping of critically ill patients with coronavirus-19 sepsis: a prospective cohort study. J Intensive Care. 2021;9(1):12.

14. LI X, PAN X, LI Y, AN N, XING Y, YANG F, et al. Cardiac injury associated with severe disease or ICU admission and death in hospitalized patients with COVID-19: a meta-analysis and systematic review. Crit Care. 2020;24(1):468.

15. GIUSTINO G, CROFT LB, STEFANINI GG, BRAGATO R, SILBIGER JJ, VICENZI M, et al. Characterization of Myocardial Injury in Patients With COVID-19. J Am Coll Cardiol. 2020;76(18):2043-2055.

16. PEIRÓ ÓM, CARRASQUER A, SÁNCHEZ-GIMENEZ R, LAL-TREHAN N, DEL-MORAL-RONDA V, BONET G, et al. Biomarkers and short-term prognosis in COVID-19. Biomarkers. 2021;26(2):119-126.

17. SHOAR S, HOSSEINI F, NADERAN M, MEHTA JL. Meta-analysis of Cardiovascular Events and Related Biomarkers Comparing Survivors Versus Non-survivors in Patients With COVID-19. Am J Cardiol. 2020;135:50-61.

18. LI J, ZHANG Y, WANG F, LIU B, LI H, TANG Z, et al. Cardiac damage in patients with the severe type of coronavirus disease 2019 (COVID-19). BMC Cardiovasc Disord. 2020;20(1):479.

19. MU S, WEI W, JIN C, PU N, YU K, GU G, et al. Risk factors for COVID-19 patients with cardiac injury: pulmonary ventilation dysfunction and oxygen inhalation insufficiency are not the direct causes. Aging (Albany NY). 2020;12(23):23464-23477.

20. SHAH P, DOSHI R, CHENNA A, OWENS R, COBB A, IVEY H, et al. Prognostic Value of Elevated Cardiac Troponin I in Hospitalized Covid-19 Patients. Am J Cardiol. 2020;135:150-153.

21. ÖZYILMAZ S, ERGÜN ALIŞ E, ERMIŞ E, ALLAHVERDIYEV S, UÇAR H. Assessment of the Relationship between Mortality and Troponin I Levels in Hospitalized Patients with the Novel Coronavirus (COVID-19). Medicina (Kaunas). 2020;56(12):693.

22. MEDETALIBEYOGLU A, EMET S, SENKAL N, AYDOGAN M, KOSE M, TUKEK T. Cardiovascular view of intermediate and high-risk COVID-19 patients: single-centre experience with low mortality and intensive care hospitalisation rates. Cardiovasc J Afr. 2021;32(2):79-86.

23. ARCARI L, LUCIANI M, CACCIOTTI L, MUSUMECI MB, SPUNTARELLI V, PISTELLA E, et al. Incidence and determinants of high-sensitivity troponin and natriuretic peptides elevation at admission in hospitalized COVID-19 pneumonia patients. Intern Emerg Med. 2020;15(8):1467-1476.

24. STEFANINI GG, CHIARITO M, FERRANTE G, CANNATA F, AZZOLINI E, VIGGIANI G, et al. Early detection of elevated cardiac biomarkers to optimise risk stratification in patients with COVID-19. Heart. 2020;106(19):1512-1518.

25. QIN JJ, CHENG X, ZHOU F, LEI F, AKOLKAR G, CAI J, et al. Redefining Cardiac Biomarkers in Predicting Mortality of Inpatients With COVID-19. Hypertension. 2020;76(4):1104-1112.

26. SALVATICI M, BARBIERI B, CIOFFI SMG, MORENGHI E, LEONE FP, MAURA F, et al. Association between cardiac troponin I and mortality in patients with COVID-19. Biomarkers. 2020;25(8):634-640.

27. CAO J, ZHENG Y, LUO Z, MEI Z, YAO Y, LIU Z, et al. Myocardial injury and COVID-19: Serum hs-cTnI level in risk stratification and the prediction of 30-day fatality in COVID-19 patients with no prior cardiovascular disease. Theranostics. 2020;10(21):9663-9673.

28. HODGES G, PALLISGAARD J, SCHJERNING OLSEN AM, MCGETTIGAN P, ANDERSEN M, KROGAGER M, et al. Association between biomarkers and COVID-19 severity and mortality: a nationwide Danish cohort study. BMJ Open. 2020;10(12):e041295.

29. RAAD M, DABBAGH M, GORGIS S, YAN J, CHEHAB O, DAGHER C, et al. Cardiac Injury Patterns and Inpatient Outcomes Among Patients Admitted With COVID-19. Am J Cardiol. 2020;133:154-161. 
30. TORAIH EA, ELSHAZLI RM, HUSSEIN MH, ELGAML A, AMIN M, EL-MOWAFY M, et al. Association of cardiac biomarkers and comorbidities with increased mortality, severity, and cardiac injury in COVID-19 patients: A meta-regression and decision tree analysis. J Med Virol. 2020;92(11):2473-2488.

31. HE X, WANG L, WANG H, XIE Y, YU Y, SUN J, et al. Factors associated with acute cardiac injury and their effects on mortality in patients with COVID-19. Sci Rep. 2020;10(1):20452.

32. YAO Q, NI J, HU TT, CAI ZL, ZHAO JH, XIE QW, et al. Clinical characteristics and outcomes in coronavirus disease 2019 (COVID-19) patients with and without hypertension: a retrospective study. Rev Cardiovasc Med. 2020;21(4):615-625.

33. ALOISIO E, CHIBIREVA M, SERAFINI L, PASQUALETTI S, FALVELLA FS, DOLCI A, et al. A Comprehensive Appraisal of Laboratory Biochemistry Tests as Major Predictors of COVID-19 Severity. Arch Pathol Lab Med. 2020;144(12):1457-1464.

34. SINGH N, ANCHAN RK, BESSER SA, BELKIN MN, CRUZ MD, LEE L, et al. High sensitivity Troponin-T for prediction of adverse events in patients with COVID-19. Biomarkers. 2020;25(8):626-633.

35. LI C, JIANG J, WANG F, ZHOU N, VERONESE G, MOSLEHI JJ, et al. Longitudinal correlation of biomarkers of cardiac injury, inflammation, and coagulation to outcome in hospitalized COVID-19 patients. J Mol Cell Cardiol. 2020;147:74-87.

36. POTERUCHA TJ, ELIAS P, JAIN SS, SAYER G, REDFORS B, BURKHOFF D, et al. Admission Cardiac Diagnostic Testing with Electrocardiography and Troponin Measurement Prognosticates Increased 30-Day Mortality in COVID-19. J Am Heart Assoc. 2021;10(1):e018476.

37. SI D, DU B, NI L, YANG B, SUN H, JIANG N, et al. Death, discharge and arrhythmias among patients with COVID-19 and cardiac injury. CMAJ. 2020;192(28):E791-E798.

38. ZHOU M, WONG CK, UN KC, LAU YM, LEE JC, TAM FC et al. Cardiovascular sequalae in uncomplicated COVID-19 survivors. PLoS One. 2021;16(2):e0246732.

39. GHIO S, BALDI E, VICENTINI A, LENTI MV, DI SABATINO A, DI MATTEO A, et al. Cardiac involvement at presentation in patients hospitalized with COVID-19 and their outcome in a tertiary referral hospital in Northern Italy. Intern Emerg Med. 2020;15(8):1457-1465.

40. LI J, GUO T, DONG D, ZHANG X, CHEN X, FENG Y, et al. Defining heart disease risk for death in COVID-19 infection. QJM. 2020;113(12):876-882.

41. BELARTE-TORNERO LC, VALDIVIELSO-MORÉ S, VICENTE ELCANO M, SOLÉ-GONZÁLEZ E, RUÍZ-BUSTILLO S, CALVO-FERNÁNDEZ A, et al. Prognostic Implications of Chronic Heart Failure and Utility of NT-proBNP Levels in Heart Failure Patients with SARS-CoV-2 Infection. J Clin Med. 2021;10(2):323.

42. ZYLlA MM, MERLE U, VEY JA, KOROSOGLOU G, HOFMANN E, MÜLlER M, et al. Predictors and Prognostic Implications of Cardiac Arrhythmias in Patients Hospitalized for COVID-19. J Clin Med. 2021;10(1):133.

43. MANOCHA KK, KIRZNER J, YING X, YEO I, PELTZER B, ANG B, et al. Troponin and Other Biomarker Levels and Outcomes Among Patients Hospitalized With COVID-19: Derivation and Validation of the $\mathrm{HA}_{2} \mathrm{~T}_{2}$ COVID-19 Mortality Risk Score. J Am Heart Assoc. 2021;10(6):e018477.

44. MAHMOUD-ELSAYED HM, MOODY WE, BRADLOW WM, KHAN-KHEIL AM, SENIOR J, HUDSMITH LE, et al. Echocardiographic Findings in Patients With COVID-19 Pneumonia. Can J Cardiol. 2020;36(8):1203-1207.

45. CHEN LQ, BURDOWSKI J, MARFATIA R, WEBER J, GLIGANIC K, DIAZ N, et al. Reduced cardiac function is associated with cardiac injury and mortality risk in hospitalized COVID-19 Patients. Clin Cardiol. 2020;43(12):1547-1554.

46. VAN DEN HEUVEL FMA, VOS JL, KOOP Y, VAN DIJK APJ, DUIJNHOUWER AL, DE MAST Q, et al. Cardiac function in relation to myocardial injury in hospitalised patients with COVID-19. Neth Heart J. 2020;28(7-8):410-417.

47. LAZZERI C, BONIZZOLI M, BATACCHI S, CIANCHI G, FRANCI A, FULCERI GE, et al. Cardiac Involvment in COVID-19Related Acute Respiratory Distress Syndrome. Am J Cardiol. 2020;132:147-149.

48. GHIO S, BALDI E, VICENTINI A, LENTI MV, DI SABATINO A, DI MATTEO A, et al. Cardiac involvement at presentation in patients hospitalized with COVID-19 and their outcome in a tertiary referral hospital in Northern Italy. Intern Emerg Med. 2020;15(8):1457-1465.

49. SONSOZ MR, ONCUL A, CEVIK E, ORTA H, YILMAZ M, AYDUK GOVDELI E, et al. Wide QRS Complex and Lateral ST-T Segment Abnormality Are Associated With Worse Clinical Outcomes in COVID-19 Patients. Am J Med Sci. 2021;361(5):591-597.

50. SANGHVI SK, SCHWARZMAN LS, NAZIR NT. Cardiac MRI and Myocardial Injury in COVID-19: Diagnosis, Risk Stratification and Prognosis. Diagnostics (Basel). 2021;11(1):130.

51. KNIGHT DS, KOTECHA T, RAZVI Y, CHACKO L, BROWN JT, JEETLEY PS, et al. COVID-19: Myocardial Injury in Survivors. Circulation. 2020;142(11):1120-1122.

52. LAI CC, SUNG MI, HO CH, LIU HH, CHEN CM, CHIANG SR, et al. The prognostic value of N-terminal proB-type natriuretic peptide in patients with acute respiratory distress syndrome. Sci Rep. 2017;7:44784.

53. UELAND T, HEGGELUND L, LIND A, HOLTEN AR, TONBY K, MICHELSEN AE, et al. Elevated plasma sTIM-3 levels in patients with severe COVID-19. J Allergy Clin Immunol. 2021;147(1):92-98.

54. BANSAL A, KUMAR A, PATEL D, PURI R, KALRA A, KAPADIA SR, et al. Meta-analysis Comparing Outcomes in Patients With and Without Cardiac Injury and Coronavirus Disease 2019 (COVID 19). Am J Cardiol. 2021;141:140-146.

55. PRANATA R, HUANG I, LUKITO AA, RAHARJO SB. Elevated N-terminal pro-brain natriuretic peptide is associated with increased mortality in patients with COVID-19: systematic review and meta-analysis. Postgrad Med J. 2020;96(1137):387-391.

56. GAO L, JIANG D, WEN XS, CHENG XC, SUN M, HE B, et al. Prognostic value of NT-proBNP in patients with severe COVID-19. Respir Res. 2020;21(1):83.

57. ABDEEN Y, KAAKO A, ALNABULSI M, OKEH A, MENG W, MILLER R. The prognostic effect of brain natriuretic peptide levels on outcomes of hospitalized patients with COVID-19. Avicenna J Med. 2021;11(1):20-26. 
58. ALMEIDA JUNIOR GLG, BRAGA F, JORGE JK, NOBRE GF, KALICHSZTEIN M, FARIA PMP, et al. Prognostic Value of Troponin-T and B-Type Natriuretic Peptide in Patients Hospitalized for COVID-19. Valor Prognóstico da Troponina T e do Peptídeo Natriurético Tipo B em Pacientes Internados por COVID-19. Arq Bras Cardiol. 2020;115(4):660-666.

59. MYHRE PL, PREBENSEN C, STRAND H, RØYSLAND R, JONASSEN CM, RANGBERG A, et al. Growth Differentiation Factor 15 Provides Prognostic Information Superior to Established Cardiovascular and Inflammatory Biomarkers in Unselected Patients Hospitalized With COVID-19. Circulation. 2020;142(22):2128-2137

Received $2^{\text {nd }}$ June 2021 